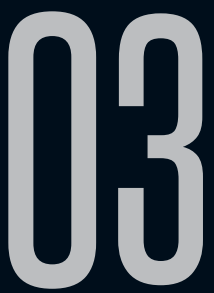

\title{
AMBIGUIDADES DO VAMPIRO NA LITERATURA OITOCENTISTA
}

Juliana de Souza Topan (Unicamp)

Recebido em 14 mar 2019. Juliana de Souza Topan é Doutoranda em Teoria e Aprovado em 27 jun 2019. História Literária na UNICAMP, Mestre em Educação e professora no IFSP, campus São Paulo Pirituba, onde atua na graduação em Letras, nas áreas de Literaturas em Língua Portuguesa, Literatura Infantil e Literatura Juvenil. É membro do CELTA (Centro de Estudos de Literatura, Teorias do fenômeno religioso e Artes, IEL/UNICAMP) e do LINTEC (Grupo de Pesquisa em Linguagem, Tecnologia e Cultura, IFSP). Áreas de interesse e pesquisa: literatura brasileira; mitologia e literatura; literatura infantil; literatura juvenil; ensino de literatura. Lattes: http://lattes. cnpq.br/3328777524800655. E-mail: juliana.topan@ifsp. edu.br.

Resumo: O vampiro é uma personagem mítica e literária que, nas últimas décadas, esteve presente em obras literárias, televisivas e cinematográficas de grande sucesso de público, como os filmes Drácula de Bram Stoker (1992) e Entrevista com o vampiro (1994), a série televisiva Buffy, a caça-vampiros (1997-2003) e a saga Crepúsculo, de Stephenie Meyer (2005-2008). Analisando narrativas vampirescas contemporâneas, David Roas aponta uma "domesticação" ou "naturalização do monstro", já que vampiros convivem com humanos e se convertem em "mais uma raça ou espécie", entre tantas no mundo. Roas identifica que 
o processo de humanização da figura do vampiro e a atenuação de seus aspectos monstruosos teriam se iniciado com a publicação de Entrevista com o vampiro (1976), de Anne Rice, a partir da caracterização de Louis como um vampiro belo, sensível e culpado por matar pessoas. Entretanto, ao analisar poemas e narrativas do final do século XVIII e do século XIX, o presente artigo pretende explicitar que tal processo se inicia muito antes, na transição da personagem vampiresca do universo mítico para obras literárias. Conclui-se, a partir da análise dos poemas Christabel, de Coleridge (1795) e A noiva de Corinto, de Goethe (1797), do conto A morta amorosa, de T. Gautier (1836), e dos romances Carmilla, a vampira de Karstein, de S. Fanu (1874) e Drácula, de B. Stoker (1897), que, desde o século XVIII, encontra-se uma ambiguidade na caracterização dos vampiros em obras literárias, nas quais se encontra uma alternância entre a descrição humanizada e monstruosa dos vampiros.

Palavras-chave: Vampiros; Imagens vampirescas; Mutações do vampiro; Vampiros no século XIX.

Abstract: The vampire is a mythical and literary character who in the last decades has appeared in literary, television and cinematographic pieces of great success, such as Bram Stoker's Dracula (1992) and Interview with the vampire (1994) movies; the television series Buffy, the vampire slayer (1997-2003); and the Twilight saga, by Stephenie Meyer (20052008). Analyzing contemporary vampiric narratives, David Roas suggests a "monster domestication" or "naturalization", since vampires and humans coexist, and the former turn into "one more race or species" among others in the world. Roas identifies that the humanization process of the vampire's figure and the mitigation of his monstrous' aspects have started with the release of Interview with the vampire (1976), by Anne Rice, since Louis' description as a sensitive and beautiful vampire, who feels guilty of killing people. 
However, analyzing eighteenth and nineteenth centuries poems and narratives, this article seeks to highlight that this process has started early, in the transition of the vampiric character from mythical universe to literary pieces. Considering poems such as Christabel, by Coleridge (1795), and The bride of Corinth, by Goethe (1797); the short story The dead woman in love, by T. Gautier (1836); and novels as Carmilla, the vampire of Karstein, by S. Fanu (1874), and Dracula, by B. Stoker (1897), we conclude that since the eighteenth century, there is an ambiguity in vampires characterization on literary pieces, in which there is an alternation between a humanized and a monstrous vampire description.

Keywords: Vampires; Vampiric Images; Vampiric mutations; Vampires in nineteenth century.

\section{INTRODUÇÃO}

A expressão "as metamorfoses do vampiro", cunhada por Charles Baudelaire como título de um dos poemas de seu famoso livro Les fleurs du mal (1857, p.206) já se tornou um lugar comum na crítica de narrativas vampirescas, sejam literárias ou cinematográficas. Há mais de duzentos anos, o vampiro deixou de estar presente apenas nas crenças e mitos para integrar a literatura da Europa e, posteriormente, de outros continentes, e, nesse processo, inúmeras foram as mudanças observadas na constituição e caracterização deste personagem. É fato notável, ademais, não apenas sua permanência, mas sua importância na cultura do século XX: depois da publicação do romance de Bram Stoker (1897), a figura do vampiro se populariza não apenas na literatura, mas, sobretudo, através do cinema. Além de clássicos como Nosferatu, de W. Murnau (1922), calcula-se que, até meados dos anos 1990, 
foram produzidos uma média de 650 filmes sobre vampiros desde o início do cinema (SCHIMIDT, Apud LECOUTEUX, 2005, p.11).

A prova da vitalidade deste personagem é sua recorrente adaptação em diferentes gêneros narrativos e momentos históricos. Recentemente, vampiros novamente garantiram sucesso de público em livrarias e cinemas, em um ciclo que podemos identificar a partir dos anos 1990 (CLARK, 2005), com o filme Drácula de Bram Stoker, de Francis F. Coppola (1992), a série de romances Os diários do vampiro, de L. J. Smith (1991-1992), o filme Entrevista com o vampiro, de Neil Jordan (1994), a série de TV Buffy, a caça-vampiros (criada por Joss Whedon, exibida nos EUA entre 1997-2003), chegando ao século XXI com a publicação da série Crepúsculo, de Stephenye Meyer (2005-2008). Composta por quatro romances e adaptada para o cinema em cinco filmes, entre 2008 e 2012, a série ficou mundialmente famosa, apresentando aos leitores a história narrada por Isabella Swan (ou simplesmente Bella), uma garota de 17 anos que se apaixona por Edward Cullen, um vampiro que frequenta a mesma escola que ela. A ideia de um vampiro - ser marginal, monstruoso - frequentar uma escola - espaço comum e normativo - causa estranhamento, e isso se configura em uma das inovações da narrativa de Meyer, como veremos a seguir. Embora em Buffy, a caça-vampiros, narrativas sobrenaturais e vampirescas (muitas vezes, com elementos de paródia, que ironizam os clichês das narrativas de terror) já sejam representadas no espaço escolar, por protagonistas adolescentes (CLARK, 2005, p.48-50), a saga de Meyer vai além, já que não reproduz o antagonismo entre vampirosalgozes e humanos-vítimas - não há, sequer, a tradicional figura do (ou da, considerando Buffy) caça-vampiros. 
A saga Crepúsculo chamou a atenção do público e da crítica ao deslocar o vampiro da categoria de antagonista para a de herói, colocando em Edward Cullen uma ética cristã aparentemente rara em vampiros de obras anteriores. Edward não ataca humanos, mas alimenta-se do sangue de animais que caça; não utiliza seus poderes para prejudicar pessoas, mas para protegêlas; e, apaixonado por Isabella Swan, tenta afastá-la, temendo os perigos pelos quais ela passaria caso se relacionasse com ele. Não conseguindo manter-se longe da amada, ele a protege não só de outros vampiros, mas de si próprio, recusando-se a ter relações sexuais com ela até o casamento, o que Lydia Kokkola (2010, p.166) identifica como um reflexo de valores mórmons e do movimento cristão True Love Waits $(T L W)^{1}$ na narrativa. Embora Bella o provoque e deseje consumar o ato sexual, Edward resiste, temendo descontrolar-se e machucá-la com sua força vampírica, ou não resistir e beber seu sangue, transformando-a também em vampira. Em suma, um vampiro não só generoso e altruísta, mas controlado, casto.

Outro aspecto interessante da obra é apresentar vampiros que vivem em família, embora isso não se generalize, pois "são poucos os vampiros que vivem realmente em meio aos seres humanos, a maior parte deles é nômade e caça em grupos de dois ou três" (ULIANO, 2017, p.192). Entretanto, embora sejam uma exceção nesse universo ficcional, os Cullen aparecem, aos olhos da 1 True Love Waits (TLW) pode ser traduzido por "O Verdadeiro Amor Espera", movimento evangélico propagado nos Estados Unidos pela LyfeWay Christian Resources desde o início dos anos 1990. Prega a abstinência sexual entre jovens, incentivando-os a fazer um voto de castidade até entrarem em um "casamento bíblico". A Brigham Young University (BYU), a universidade Mórmon de Utah, onde Meyer realizou seus estudos, requeria que seus estudantes aderissem a um código de honra próximo aos princípios do TLW (KOKKOLA 2011, p.166). 
população de Forks, uma pequena cidade do oeste estadunidense, como uma família comum, apesar dos hábitos reclusos e frequentes saídas para caçadas: os filhos frequentam a escola, Carlisle trabalha no hospital, Esme cuida da casa e dos adolescentes.

Os Cullen saem à luz do dia, moram em uma casa branca, não dormem em caixões, não têm aparência putrefata ou cadavérica, apesar de serem pálidos e frios. Ao contrário, Isabella frequentemente se refere ao cheiro agradável e à beleza incomparável de seu amado. Além disso, em Crepúsculo, vampiros não são criaturas demoníacas (não há qualquer menção de terem sido gerados pelo Diabo ou terem qualquer contato com ele) e, no caso dos Cullen, alguns até acreditam em Deus, como é o caso de Edward e Carlisle, que conserva em seu escritório um crucifixo de madeira renascentista (MEYER, 2009, p.36), que pertencia à sua aldeia natal (lembrança do tempo em que era humano e filho de um pastor protestante).

Ao apresentar vampiros que constituem uma família (no sentido não apenas social, mas afetivo), que interagem com humanos e participam de suas comunidades (em seu nível institucional, inclusive), a saga Crepúsculo traz inovações significativas na representação dos vampiros, muitas delas já analisadas pela crítica. Nesse sentido, uma das contribuições relevantes é a de David Roas, professor da Universidade Autônoma de Barcelona. Com base na análise da referida saga, bem como de outras produções literárias, televisivas e cinematográficas contemporâneas sobre vampiros, Roas afirma que há uma tendência de banalização ou domesticação do monstro nas narrativas contemporâneas, nas quais o vampiro não apenas é "despojado de sua dimensão metafisicamente 
ameaçadora e subversiva", mas também apresenta algo "atrativo e estilizado, frequentemente adolescente e, inclusive, apaixonado" $(2014, \text { p.110 })^{2}$.

Para Roas, o "vampiro naturalizado", que se constitui como uma "raça ou espécie a mais entre as que povoam o mundo" (2012, p.451) - daí a possibilidade de integração com a espécie humana tem em Edward Cullen, pelas características acima descritas, sua figura exemplar. O crítico espanhol, porém, identifica a figura do "vampiro humanizado", antes que a do vampiro domesticado ou naturalizado apareça na cultura contemporânea. Segundo Roas, a atenuação dos traços monstruosos e a ênfase nos traços humanos se inicia com as obras da romancista americana Anne Rice e com a já referida adaptação cinematográfica do romance Drácula, de Bram Stoker, por Francis Copolla.

No primeiro caso, o romance Entrevista com o vampiro (1976) coloca em cena Louis, um vampiro sensível, que tem crises de consciência em matar humanos para sobreviver, que Roas descreve como "um depressivo existencialista" (2014, p.113) ou "o primeiro vampiro existencialista da história" (2012, p.446). Salma Ferraz (2017, p.15/16), professora da Universidade Federal de Santa Catarina, também postula a "humanização" de Loius, descrevendo-o como um vampiro "atormentando pela sua essência", que "não consegue se divorciar de vez de sua natureza humana e sensível". Em outras palavras, Ferraz (2017, p.16) ressalta em Louis a figura de um "vampiro que não deu certo", ou seja, que nunca deixou de ser humano, que nunca se transformou completamente em monstro.

2 Tradução nossa. No original: “(...) no sólo se le desposee de sua dimensión metafísicamente amenazadora y subversiva, sino que encima se le representa atractivo y estilizado, a menudo como adolescente y, incluso, enamorado". 
No segundo caso, o filme de Copolla constrói uma justificativa (inexistente no romance) para a ida de Drácula a Londres: ao ver um retrato de Mina Murray, Drácula reconhece a reencarnação de sua amada, que se suicidara há séculos (por acreditar que ele tinha morrido em uma batalha). Assim, ele atravessa oceanos e luta contra todos para reencontrá-la, convertendo-se em um "romântico apaixonado" (ROAS, 2014, p.113), bem diferente do monstro criado por Stoker. A narrativa, portanto, "deixa de ser um romance de terror para passar a ser uma história de amor" (LUCENA, 2010, Apud ROAS, 2012, p.449). A imagem de Drácula apresentada por Coppola tornou-se tão difundida que, inclusive, alguns autores passam a considerar o personagem do romance (e não apenas o do filme) um "herói romântico", como é o caso de Lynn S. Clark (2005, p.52), que, descrevendo o vampiro Angel (da série Buffy, a caça-vampiros), afirma que "ele é um herói trágico, falho e romântico, com ecos do Drácula de Stoker"”3.

Entretanto, em uma leitura atenta de poemas e narrativas vampirescas do final do século XVIII e, principalmente, do século XIX, é possível perceber que esse processo de atenuação dos traços monstruosos do vampiro, sua humanização e sua caracterização "estilizada" - atrativa, sedutora e até romântica - se inicia bem antes das narrativas de Rice e Copolla, mas remonta à transição da personagem do vampiro da narrativa mítica para a narrativa literária, como doravante pretendo demonstrar.

\section{VAMPIROS MONSTRUOSOS}

Para uma compreensão exata do que Roas chama de "banalização do monstro", é necessário remontar à origem do 3 Tradução nossa. No original: "He is a tragic, flawed romantic hero, with echoes of Stoker's Dracula (...)". 
vampiro, personagem que, antes de sua inserção na literatura, pertence à esfera do mito. Segundo Lecouteux (2005), o mito vampiresco está relacionado ao temor dos mortos, especialmente à possibilidade de que, por condições incomuns de sua morte, ou por algum descuido dos vivos nos rituais fúnebres, aqueles pudessem voltar para atormentar e matar seus amigos e entes queridos, ou até mesmo toda a comunidade a que pertenciam.

Em seu livro Totem e tabu (2012), Freud analisa tabus referentes aos contatos com os mortos em sociedades tribais e conclui que o temor de evocar ou de estabelecer contato com uma pessoa morta relaciona-se não apenas com o "natural horror pelo cadáver e pelas mudanças que logo nele se observam", mas também com o medo da "presença e o retorno do espírito do morto", de sua alma "transformada em demônio", para o qual realizam "bom número de cerimônias a fim de mantê-lo distante" (2012, p.34). Citando Rudolf Kleinpaul (1898), Freud (2012, p.35) afirma que: "originalmente (...) todos os mortos eram vampiros, todos tinham um rancor aos vivos e cuidavam de molestá-los e roubar-lhes a vida" e que, posteriormente, a "malevolência dos mortos limitava-se às categorias a que se tinha de reconhecer um direito particular ao rancor" (p.35), ou seja, aqueles cuja vida e/ou morte se dava em condições consideradas anormais, isto é, fora das normas da natureza, da sociedade ou da moralidade. Assim, os que não recebiam os ritos fúnebres adequados, os que morriam precoce e subitamente (especialmente suicidas e assassinados), deixando tarefas inacabadas, conflitos mal resolvidos, promessas não cumpridas; ou os que transgrediam a moral em vida, todos "os marginais, os sacrílegos, os ciumentos, os que foram maltratados em vida e sentem vontade de se vingar" 
(LECOUTEUX, 2005, p.41-42), podiam se tornar mortos malditos, recusados pelo além-túmulo, impedidos de concluir o "transpasse', no sentido etimológico do termo, ou seja, passagem para o outro lado" (LECOUTEUX, 2005, p.40).

Dessa forma, o temor dos mortos que está relacionado ao mito do vampiro se reafirma em sua condição de cadáver que permanece, isto é, que não se decompõe, não desaparece, configurando-se em presença física, portanto impossível de ser ignorada, da morte entre os vivos. Nesse sentido, torna-se um "significante", segundo o psicanalista Max Kohn:

De uma fronteira mais ou menos porosa ou estanque entre os vivos e os mortos, sem suturar a circulação entre os dois. (...) O vampiro concentra e canaliza nele, como poder, figura e imagem também, tudo o que há de indeterminação em nós quanto à distinção entre a vida e a morte, todo um vazio entre a vida e a morte. (2012, p.303)

Assim, nas crenças de povos do leste europeu, em que se basearam as primeiras publicações literárias sobre a figura do vampiro, este era um monstro "em um sentido físico, porque mata os seres humanos para se alimentar deles (...) e em um sentido metafísico, porque é um ser impossível, alguém que retorna do túmulo em outra forma de existência" (ROAS, 2012, p.442). Um ser que retorna da morte em seu próprio corpo, para atormentar os vivos e matá-los - essa simples caracterização, proveniente dos mitos do leste europeu, prevalecia nas primeiras narrativas escritas sobre vampiros, que não eram, propriamente, literárias.

De fato, os primeiros textos sobre vampiros que se difundiram na Europa eram relatórios de autoridades, seguidos por artigos e 
dissertações de teólogos e filósofos. Embora possa parecer bizarra a ideia de um tema pertencente à esfera do sobrenatural mover as preocupações de militares, médicos e acadêmicos, tais relatos resultaram de investigações feitas em algumas vilas e cidades do leste europeu, onde a mortandade de pessoas devido ao suposto ataque de vampiros começou a chamar a atenção de autoridades. Um dos casos mais famosos ocorreu na cidade de Medvegia, na Sérvia, em 1731, para onde uma comissão científica, liderada pelo cirurgião do Regimento de Campo da Infantaria Austríaca, Johannes Fluchinger, dirigiu-se a fim de investigar a morte de 17 pessoas, em decorrência de supostos ataques de um morto-vivo, Arnold Paole (o processo judicial de exumação se encontra reproduzido em LECOUTEUX, 2005, p.179-184).

Fluchinger redigiu um relatório, apresentado ao imperador em 1732, no qual confirmava a existência dos vampiros; publicado no mesmo ano em Belgrado e em Berlim, pela Sociedade Real Prussiana de Ciências, foi reproduzido em obra intitulada Visum et Repertum, que circulou pelo continente europeu, gerou impacto e levou padres, teólogos e filósofos a escreverem sobre vampiros (LECOUTEUX, 2005, p.13; SILVA, Apud COSTA, 2010, p.21-23). Um dos mais relevantes foi Dom Augustin Calmet, que publicou Traités sur les apparitions des anges, des démons et des esprits, et sur les revenants, et vampires de Hongrie, de Moravie, et etc em 1751, em dois volumes. No segundo, o sacerdote e acadêmico francês compila todas as principais publicações sobre vampiros até a metade do século XVIII, analisando-as a partir dos dogmas católicos.

Os relatos compilados por D. Augustin Calmet apresentam o vampiro como um revenant en corps, isto é, uma criatura sobrenatural 
que volta da morte em seu próprio corpo. Assim Calmet define o vampiro, no primeiro capítulo do segundo volume de sua obra:

São os homens mortos desde um tempo considerável, às vezes mais às vezes menos longo, que saem de seus túmulos e vêm inquietar os vivos, sugam-Ihes o sangue, aparecem-Ihes, fazem barulho à suas portas e em suas casas, e enfim causa-Ihes frequentemente a morte. Dá-se a eles o nome de Vampiros ou de Oupires, que significa, diz-se, em Esloveno, um sanguessuga ${ }^{4}$. (1751, p.2)

Nesta definição, o autor resume características que aparecerão em relatos, provenientes de vários países, sobre vampiros. Nota-se, ao longo dos relatos, que o corpo que se levanta do túmulo, aparece aos vivos, importuna-lhes, suga-Ihes o sangue e causa-lhes a morte é visto como uma aberração, uma criatura maldita e perigosa, que é preciso não apenas eliminar, mas garantir que tal eliminação seja absoluta e irreversível, através da decapitação e queima do corpo. Tais relatos reproduzem a imagem do vampiro no folclore do leste europeu: um cadáver que se levanta, que anda, que persegue homens e animais para exclusivamente sugar-Ihes o sangue (SILVA, 2010, p.11), cujos aspectos cadavéricos são assustadores ou repugnantes:

Quando foram retirados da terra, eles [os cadáveres] pareciam vermelhos, tendo os membros flexíveis e maleáveis, sem vermes e sem podridão, mas não sem um muito grande fedor ${ }^{5}$. (CALMET, 1751, p.35)

4 Tradução nossa. No original: “(...) sont des hommes morts depuis un temps considérable, quelquefois plus quelquefois moins long, qui sortent de leurs tombeaux \& viennent inquiéter les vivans, leur sucent le sang, leur apparoissent, font le tintamare à leurs portes \& dans leurs maisons, \& enfin leur causent souvent la mort. On leur donne le nom de Vampires ou d'Oupires, qui signifie, dit-on, en Esclavon une sang-sue".

5 Tradução nossa. No original: "(...) quand on les a tirés de terre, ils ont paru vermeils, ayant les membres souples \& maniables, sans vers \& sans pourriture; mais non sans une très-grande puanteur". 
Eles aparecem desde o meio dia até a meia noite, e vêm sugar o sangue dos homens e dos animais vivos em tão grande abundância, que às vezes ele Ihes sai pela boca, pelo nariz e principalmente pelas orelhas, e que às vezes o cadáver nada no seu sangue, derramado sobre o seu caixão. Este revivido ou Oupire saído de seu túmulo, ou um Demônio sob sua figura, vai à noite beijar e apertar violentamente seus próximos e seus amigos, e lhes suga o sangue, até enfraquecê-los, extenuá-los e Ihes causar enfim a morte ${ }^{6}$. (CALMET, 1751, p.60)

Tal imagem monstruosa, física e metafisicamente, como menciona Roas, parece muito distante dos Cullen, vampiros cuja beleza é comparada a modelos de uma revista de moda, ou à de um anjo:

E ainda, eles eram todos totalmente parecidos. Cada um deles era pálido como gesso, os mais pálidos dos estudantes que viviam nessa cidade sem sol. (...) seus narizes, todas as suas feições eram corretas, perfeitas, angulares.

Mas não era por tudo isso que eu não conseguia desviar o olhar.

Eu olhava porque os rostos deles, tão diferentes, tão parecidos, eram devastadoramente, inumanamente bonitos. Eram rostos que você nunca espera ver exceto talvez nas páginas embelezadas de uma revista de moda. Ou pintadas por um velho mestre como o rosto de um anjo. Era difícil decidir quem era o mais bonito7. (MEYER, 2008, p.16-17)

6 Tradução nossa. No original: "Ils aparoissent depuis midi jusqu'a minuit, \& viennent sucer le sang des hommes et des animaux vivans en si grand abondance, que quelquefois il leur sort par la bouche, par le nez, \& principalement par les oreilles, \& que quelquefois le cadavre nage dans son sang répandu dans son cercueil. Ce rédivive ou Oupire sorti de son tombeau, ou un Démon sou sa figure, va la nuit embrasser \& serrer violemment ses proches et ses amis, \& leur suce le sang, jusqu'à les effoiblir, les exténuer \& leur causer enfin la mort".

7 Tradução nossa. No original: "And yet, they were all exactly alike. Every one of them was chalky pale, the palest of all the students living in this sunless town. (...) their noses, 
A descrição vampiresca de Meyer data do início do século XXI; porém, muito antes disto, já no século XVIII, encontramos, na literatura, uma descrição atraente da figura do vampiro, como veremos a seguir.

\section{MONSTRO MÍTICO E PERSONAGEM LITERÁRIA}

Depois da repercussão das obras jurídicas e teológicas acima citadas, a figura do vampiro começa a aparecer em textos literários, primeiro, na poesia, em meados do século XVIII, inclusive na obra de poetas renomados, como Goethe, que publica "A noiva de Corinto" em 1797. A partir do século XIX, aparece, pela primeira vez na prosa literária, em "O vampiro", conto de Polidori publicado em 1819 na New Montly Magazine, seguido pelo folhetim de James M. Rymer, Varney, the vampire - the feast of blood (1847, considerado o primeiro romance sobre o tema), a novela Carmilla, a vampira de Karnstein, do irlandês Sheridan Le Fanu (1872) e, enfim, o famoso Drácula, do irlandês Bram Stoker (1897). Embora os dados revelem uma predominância do tema em textos de língua inglesa, não se pode deixar de lado as importantes obras dos franceses Théophile Gautier, La morte amoureuse, de 1836, e Lautréamont, Les chants de Maldoror, de 1868-69.

Já a partir da análise dos primeiros poemas que abordam a temática vampiresca, é possível perceber que, à figura monstruosa do vampiro, agregam-se aspectos atraentes e sedutores. No poema

all their features, were straight, perfect, angular.

But all this is not why I couldn't look away.

I stared because their faces, so different, so similar, were all devastatingly, inhumanly beautiful. They were faces you never expected to see except pehaps on the airbrushed pages of a fashion magazine. Or painted by an old master as the face of an angel. It was hard to decide who was the most beautiful (...)". 
de Goethe, "A noiva de Corinto" (baseado no folclore grego e na narrativa de Flégon de Trales (século II d. C.), uma jovem surge em uma atmosfera noturna, oferecendo-se a um hóspede - era a falecida filha dos donos da casa. Há vários indícios de que se trata de uma vampira: ela é "clara como a neve, mas fria", "não Ihe pulsa o coração", e aspira "a todo sangue que tem (...) / sedenta, a debelar gente jovem" (GOETHE, Apud COSTA, 2010, p.231-233). Entretanto, sua aparência não é repugnante, pois desperta o desejo do hóspede, que Ihe implora seu amor, "mesmo que tu venhas da tumba". Ela resiste, a princípio, mas depois cede aos apelos do moço:

Selando em êxtase o amor,

Lágrimas ao desejo se mesclam;

Suga-Ihe ela à boca o calor,

Presos um ao outro se infundem.

(...)

Um singular gemido e bulício.

Em pleno alvoroço

A moça e o moço

Indícios de amor em balbucio (GOETHE, Apud COSTA, 2010, p.231).

Ao analisarmos "O vampiro", de Polidori (1818), primeiro texto literário em prosa a abordar a temática vampiresca, a imagem de Lord Ruthven é de um nobre excêntrico que fascina a sociedade londrina, também distante da descrição do morto-vivo repugnante encontrada nos relatos compilados por Calmet:

Por suas peculiaridades, o nobre era convidado a frequentar todas as casas; todos desejavam vê- 
lo, e os adeptos da diversão intensa, e que agora sentiam o peso do tédio, ficavam satisfeitos diante da oportunidade de entretenimento. Apesar do tom mortiço de seu rosto, que jamais adquiria um matiz mais quente, fosse pelo rubor da modéstia ou pela forte emoção da paixão, talvez por suas feições e seu perfil serem belos, muitas mulheres ávidas por notoriedade tentavam atrair sua atenção. (POLIDORI, Apud COSTA, 2010, p.51 - grifos meus)

Se analisarmos as imagens do vampiro nos textos acima descritos, considerando que se trata dos primeiros textos literários europeus a apresentarem esta criatura (antes circunscrita apenas à esfera dos relatos orais da tradição popular ou dos textos jurídicos e teológicos antes citados), é possível perceber uma atenuação, mas não eliminação, de suas características repugnantes em sua transição do mito à literatura. Em outras palavras, o vampiro literário não deixa de ser um monstro que suga o sangue de humanos e os mata, mas deixa de sê-lo exclusivamente para adquirir características humanas. Essa ambiguidade entre o monstruoso e o humano se tornará ainda mais evidente na análise de três importantes narrativas do século XIX: La morte amoureuse, de Gautier, Carmilla, de Fanu e Drácula, de Stoker.

\section{AMBIGUIDADE VAMPÍRICA}

La morte amoureuse, traduzida no Brasil como A morta amorosa, é uma narrativa em 1a pessoa, em que Romualdo, um padre, conta a história de uma vida dupla: apaixonado por Clarimunda, uma cortesã que se revelará, depois, uma vampira, torna-se seu amante, vivendo com ela em um palácio, em Veneza. Porém, quando il signor Romualdo adormece, ele acorda para sua vida de padre, na 
qual, quando dorme e sonha, volta à sua vida cortesã. Confuso, ele não sabe mais distinguir o que seria sonho e o que seria realidade.

Romualdo vê Clarimunda pela primeira vez na cerimônia de sua ordenação e é capturado por sua beleza, que o leva à perdição (a tradicional tópica da beleza abissal); neste sentido, a descrição da mulher oscila entre aspectos divinos e demoníacos:

A encantadora criatura se destacava sobre este fundo de sombra como uma revelação angelical. Parecia iluminada por si mesma; mais parecia emanar a luz do que recebê-la. (...)

Ela era alta, com o tamanho e o porte de uma deusa. (...) Que olhos!... com um relâmpago, eles decidiam o destino de um homem, tinham uma vida, uma limpidez, um ardor, uma umidade brilhante que jamais vi em olho humano. (...) Não sei se a chama que os iluminava era do céu ou do inferno, mas com certeza vinha de um e de outro. Esta mulher era um anjo ou um demônio, talvez ambos - certamente não saiu da costela de Eva, a mãe comum. (GAUTIER, Apud COSTA, 2010, p.123-124)

A associação da beleza e sedução de Clarimunda à tentação demoníaca se torna mais explícita nas falas do Abade Serapião: "Durante muito tempo correram histórias muito estranhas sobre essa Clarimunda... todos os seus amantes terminaram de maneira miserável ou violenta. Diziam que era uma vampira, mas para mim era Belzebu em pessoa!" (GAUTIER, Apud COSTA, 2010, p.143).

É também na fala do Abade que se explicita a condição vampiresca de Clarimunda, reforçada pelo comentário de que a pedra do seu túmulo deveria ser reforçada, pois "não é a primeira vez que ela morre" (GAUTIER, Apud COSTA, 2010, p.144). Na fala 
da própria personagem se encontra a definição do vampiro como um revenant em corps, um morto-vivo que volta ao seu próprio corpo: "O quanto sofreu minha alma, que volta a este mundo pelo poder da vontade, para reencontrar seu corpo e nele se instalar!" (GAUTIER, Apud COSTA, 2010, p.145).

Depois de morta, Clarimunda aparece para Romualdo durante o seu sono (conforme inúmeras descrições nos relatos compilados por Calmet; cena que se repetirá em narrativas posteriores, como Carmilla e Drácula), mas nem a aparência dela lhe é repugnante, nem lhe parece demoníaca:

Envolta naquele tecido fino que traía todos os contornos do seu corpo, ela mais parecia uma estátua de mármore de banhista antiga do que mulher dotada de vida. Morta ou viva, estátua ou mulher, sombra ou corpo, sua beleza era sempre a mesma. (...)

Apesar de tudo o que eu já vira, ainda não consigo acreditar que fosse um demônio, pelo menos, não parecia um demônio, ou jamais Satã escondeu melhor suas garras e cornos. Estava pousada sobre os calcanhares e se mantinha à beira do meu leito em uma posição cheia de graça e abandono. (GAUTIER, Apud COSTA, 2010, p.145-146)

O apelo sexual de Clarimunda também é explicitamente colocado pelo narrador:

Eu a amava perdidamente. Ter Clarimunda era ter vinte amantes, tanto ela era móvel, versátil e diferente de si mesma... era um verdadeiro camaleão! Clarimunda fazia qualquer um cometer com ela a infidelidade que teria cometido com outras, assumindo completamente a personalidade, 
o comportamento e o gênero de beleza feminina que aparentemente te agradasse. (GAUTIER, Apud COSTA, 2010, p.151)

Se o amor e o desejo fazem com que Romualdo veja Clarimunda como humana e mulher, um episódio revela sua condição de vampira, quando ele se corta e seu sangue desperta a sede de sua amada:

Seus olhos se iluminaram, sua fisionomia tinha uma expressão de alegria feroz e selvagem como eu jamais vira. Saltou da cama com uma agilidade animal, uma agilidade de macaco ou de gato e se precipitou sobre o ferimento, que começou a sugar com indizível volúpia. Engolia o sangue em pequenos goles, lenta e preciosamente, como um gourmet um vinho de Xerez ou de Siracusa, os olhos semicerrados; as pupilas verdes se tornaram oblongas, em vez de redondas. (GAUTIER, Apud COSTA, 2010, p.152-153 - grifos meus)

Chama a atenção os termos, destacados em negrito, que aproximam Clarimunda de uma condição de animalidade, associada à imagem do vampiro monstruoso. Mas, na sequência, o narrador descobre que Clarimunda alimentava-se dele todos os dias, dopando-o e, durante o sono, bebendo-lhe o sangue. A cena, porém, difere bastante da transcrita acima:

Ao certificar-se de que eu dormia, descobriu o meu braço, tirou um alfinete de ouro dos cabelos e começou a sussurrar:

- Uma gota, apenas uma gotinha vermelha, um rubi na ponta da minha agulha! Se ainda me amas, não posso morrer... Ah! Pobre amor! Vou beber teu lindo sangue de uma cor púrpura tão brilhante. Dorme, meu único benzinho... dorme, meu deus, minha criança, não te farei mal... tomarei da tua vida 
apenas o necessário para não extinguir a minha... Se eu não te amasse tanto, poderia decidir ter outros amantes cujas veias eu secaria... mas depois de te conhecer, tenho horror a todos os outros... Ah! Que braço lindo! Como é roliço! Como é branco! Eu jamais ousaria picar esta linda veia azul...

Dizendo isto, ela chorou e eu sentia suas lágrimas choverem no meu braço, que ela tinha nas mãos. Afinal, ela tomou a decisão, deu uma picadinha com a agulha e começou a sugar o sangue que escorreu. Embora tenha bebido só umas gotas, 0 receio de me deixar esgotado se apoderou dela e, com cuidado, envolveu-me o braço com um pequeno curativo, depois de haver esfregado na ferida um unguento que a cicatrizou de imediato. (GAUTIER, Apud COSTA, 2010, p.154)

A cena acima difere absolutamente da postura animalesca observada na anterior: Clarimunda declara seu amor e fidelidade a Romualdo, sentindo-se culpada por feri-lo para tomar seu sangue - o que a leva às lágrimas; tem receio de extenuá-lo e bebe apenas algumas gotas, curando-Ihe depois a ferida. A comparação das duas cenas evidencia a ambiguidade antes postulada, alternância entre uma imagem monstruosa e uma imagem humana do vampiro, embora, ao longo do conto, prevaleça à imagem de Clarimunda como bela, atraente, sedutora e amorosa.

A imagem da beleza e da atração também aparecem em Carmilla, agora associadas também à repulsa, ambiguidade explicitada pela própria narradora da novela de Fanu, Laura (FANU, 2010, p.62), que mora com seu pai em um castelo isolado na Estíria. No início da narrativa, eles presenciam um acidente com uma carruagem, na qual se encontravam uma mulher e sua jovem filha. 
O fato, aparentemente banal, torna-se insólito diante da urgência da mãe em seguir viagem, apesar do estado de saúde aparentemente perturbado da moça; e mais ainda pelo fato daquela, sem revelar sua identidade ou propósitos, pedir ao pai de Laura que abrigue e tome conta de sua filha. Esta é ninguém menos que Carmilla, que, ao final do romance, será identificada como Mircalla, a condessa do vilarejo abandonado de Karnstein (vizinho ao castelo), nascida em 1698 e morta há mais de um século, mas que retornara ao seu corpo como vampira.

O primeiro encontro entre Carmilla e Laura, de fato, já se tinha dado na infância da narradora, em que, numa noite, ela tem a visão de uma mulher em seu quarto, que se aproxima de sua cama e deita-se com ela. Indecisa sobre se teria sonhado ou vivido alguma espécie de transe, Laura tem muito medo e guarda a lembrança do rosto desta mulher por anos, e reconhece-o em Carmilla, que, surpreendentemente, relata-lhe que também reconhecia o seu rosto, pois sonhara com Laura em sua infância. Estabelece-se, neste episódio inicial, a ideia de uma relação entre as duas jovens que antecede o encontro físico, ou de predestinação, explicitada por Carmilla:

sinto como se nos conhecêssemos há doze anos, e sinto que já tenho direito a compartilhar a sua intimidade; em todo caso, parece que fomos destinadas, desde a tenra infância, a sermos amigas. Pergunto-me se você se sente tão estranhamente atraída por mim como eu por você. (FANU, 2010, p.62).

Se Carmilla já declara sua atração e interesse por Laura, este episódio também justifica, para esta, sua atração por Carmilla. Vale 
lembrar que a aparição de uma hóspede inusitada, no meio da noite, e que exerce atração sobre uma jovem pura e ingênua é tema do poema "Christabel", de Coleridge, escrito em 1795 e publicado em 1816. Neste, a jovem Christabel, filha de Sir Leoline, passeia nos arredores do castelo durante a noite, onde encontra uma "formosa senhorita/ Vestida em brancas sedas ao luar". O sentimento de terror pela estranha aparição se mistura à admiração de sua beleza: "Penso comigo, que visão mais terrível,/ Dar ali com uma donzela de tão formosa - / De uma beleza sem igual!" (COLERIDGE, Apud COSTA, 2010, p.239). A moça se identifica como Geraldine, de nobre linhagem; e, tendo sido capturada e depois abandonada por cinco soldados, pede ajuda e pouso a Christabel, que, fascinada, acolhe a moça e a leva a seu quarto.

Assim também Laura afirma ter ficado "fascinada" por Carmilla, "sob os mais diversos aspectos", e a descreve como "extremamente graciosa", de "pele saudável e viçosa; traços delicados e belamente delineados", os olhos, "grandes, escuros e brilhantes" e cabelos "maravilhosos", "tão fartos e tão sedosos" (FANU, 2010, p.65), em nada, portanto, lembrando uma aparência cadavérica ou monstruosa. Tal fascinação se converte em sensações contraditórias ao contato físico de Carmilla (quando esta pega-lhe a mão ou a abraça longamente) e, neste sentido, as descrições não deixam dúvida sobre a atração sexual ${ }^{8}$ entre as duas jovens:

8 Também presente em "Christabel", a relação sexual entre as jovens é sugerida nos versos: "Disse Christabel, que seja assim então!/ E como lhe foi pedido, ela o fez./ Seu belo corpo ela logo despiu,/ E então se deitou em sua perfeição. // (...) Ela se ergueu, apoiada em seu cotovelo,/ Para observar a donzela Geraldine. // Abaixo do lustre a dama se curvou,/ E lentamente seus olhos se viraram;/ E então fazendo cessar a respiração,/ Como alguém que treme, ela desfez/ A fita que trazia logo abaixo do colo:/ Seu vestido de seda, e a anágua,/ Caíram a seus pés, e inteira à mostra,/ Oh! Seu peito e suas costelas -/ Visão de sonho, não há palavras para ela (...) // No entanto, Geraldine não falava,/ Tampouco se mexia - Oh! Que olhar frio!/ (...) Ela se deitou ao lado da Virgem! - / E tomando-a em seus braços,/ Ah, Meu Deus!/ E com a voz baixa e os olhos cheios/ 
Aquelas sensações misteriosas me desagradavam. Eu sentia uma excitação estranha e perturbadora, por vezes, prazerosa, mesclada com uma vaga sensação de medo e certa aversão. (...) eu tinha consciência de um afeto que se transformava em veneração - e também de um repúdio.

Nessas ocasiões ela enrubescia levemente, contemplando meu rosto com um olhar lânguido e tórrido, e ofegando tanto que o vestido chegava a ondular. Parecia um ardor de amante; sentiame encabulada; aquilo era, ao mesmo tempo, detestável e irresistível; com os olhos cheios de desejo, ela me puxava para si, e seus lábios quentes cobriam-me de beijos as faces; ela sussurrava, quase soluçando: "És minha, serás minha; tu e eu seremos para sempre uma só". (FANU, 2010, p.68)

Embora Laura se refira aos abraços tórridos de Carmilla como "ridículos" e apresente claramente um sentimento desagradável nestes momentos de assédio, relata que sua energia "parecia se esvair" e que as palavras de Carmilla "entorpeciam minha resistência, levando-me a um estado de transe, do qual eu só me recuperava quando ela baixava os olhos" (FANU, 2010, p.67). Evidencia-se, neste trecho, além do poder de atração, o poder do vampiro de minimizar a resistência das vítimas com seu olhar, conservando-as sob um estado de transe, o que também aparecerá no Drácula, de Stoker.

Entretanto, ao longo da narrativa, Laura não se refere a isto como poderes vampíricos, uma vez que, apresentando gradativamente sua visão dos fatos enquanto jovem, considera-os características singulares, estranhas, que Ihe sugeriam (e sugerem ao leitor) que senhora de tuas palavras, Christabel!" (COLERIDGE, Apud COSTA, 2010, p.245-246) 
Carmilla não é um ser comum. Aos poucos, as sugestões de que se trata de um ser sobrenatural, ligado ao demoníaco, vão se tornando mais evidentes, com mudanças significativas na descrição da personagem - como ocorre no capítulo IV, no qual, durante uma caminhada, as jovens se deparam com um enterro, e os cantos fúnebres religiosos deixam Carmilla agressiva e com evidente malestar físico:

Sua fisionomia alterou-se de tal maneira que fiquei alarmada e, por um instante, cheia de pavor. 0 semblante se tornou escuro, e depois terrivelmente lívido; seus dentes e punhos se cerravam, enquanto ela franzia o cenho e apertava os lábios, olhando fixamente para o chão, fitando os próprios pés, e tremendo descontroladamente, como quem sofre de malária. (FANU, 2010, p.72)

Carmilla também nunca tinha sido vista rezando: pela manhã, sempre descia de seu quarto depois que a família já fizera suas orações matinais, e à noite, "jamais deixava o salão de estar para participar de nossas breves preces no vestíbulo" (FANU, 2010, p.87).

Outro indício do vampirismo monstruoso de Carmilla é o surto de mortes que se inicia depois de sua chegada, mortes de pessoas aparentemente saudáveis por causas desconhecidas, mas com uma característica comum: quando deitadas, sentiam que alguma coisa as tinha agarrado pelo pescoço, quase estrangulando-as, e, depois de alguns dias de fraqueza extrema, faleciam (FANU, 2010, p.71, 74-75). Um andarilho que passa pelo castelo oferece às jovens "amuleto contra o oupire": "Estão morrendo por causa dele a torto e a direito, e tenho aqui um amuleto infalível; basta prendê-lo ao travesseiro". Os amuletos, que eram "longas tiras de pergaminho, 
contendo códigos e diagramas cabalísticos" (FANU, 2010, p.74) não parecem afetar Carmilla, que se mostra encolerizada apenas quando o andarilho repara em seus dentes: "tem um dente dos mais afiados... longo, fino, pontudo, como uma sovela, como uma agulha" (FANU, 2010, p.75).

Os dentes longos e pontiagudos como os de uma fera, que associam o vampiro à sucção do sangue e à animalidade, são mencionados pela primeira vez na prosa literária, em Carmilla, e tornam-se uma das características mais marcantes da imagem moderna do vampiro que se difundiu pela indústria cultural, mas a associação com a animalidade é tanto mais evidente na passagem em que Laura é atacada por um "gato monstruoso":

Mas, de súbito, vi um animal preto, cor de fuligem, semelhante a um gato monstruoso. Parecia ter cerca de $1,20 \mathrm{~m}$ ou $1,50 \mathrm{~m}$, pois era do tamanho do tapete que ficava diante da lareira; e andava de um lado para o outro, com o nervosismo ágil e sinistro de uma fera enjaulada. (...) Senti quando ela pulou, suavemente, na minha cama. Os dois olhos grandes se aproximaram do meu rosto e, de repente, senti uma pontada ardida, como se duas grandes agulhas penetrassem, a dois ou quatro centímetros de distância uma da outra, fundo em meu peito. Acordei com um grito. $\mathrm{O}$ quarto estava iluminado pela vela que queimava a noite inteira, $e$ vi um vulto de mulher ao pé da cama, um pouco à direita. Ela usava um vestido escuro e largo, e tinha os cabelos soltos, cobrindo-Ihe os ombros. (...) Enquanto eu olhava, o vulto pareceu se deslocar, aproximando-se da porta; então, a porta se abriu, e a figura se foi.

Senti-me, então, aliviada e novamente capaz de respirar e de me mover. Meu primeiro 
pensamento foi que Carmilla decidira me pregar uma peça, e que eu havia esquecido de trancar a porta. Mas, correndo até lá, constatei que a porta estava trancada, como de hábito, do lado de dentro. Tive medo de abri-la - estava apavorada. (FANU, 2010, p.88-89)

Laura ainda não associa a figura do gato monstruoso a Carmilla (o que se evidenciará apenas ao final da narrativa), a qual, astutamente, relata a Laura ter tido o mesmo "pesadelo" ou "visita sombria" durante a noite. Depois deste episódio, Laura passa a sofrer de cansaço e prostração, tomada por uma melancolia "da qual eu não queria me livrar". Essa reação é acompanhada de uma crescente dedicação e adoração de Carmilla por Laura: "Quanto mais me falhavam as forças e mais deprimida eu ficava, com mais ardor ela me desejava" (FANU, 2010, p.93).

Laura torna-se visivelmente fraca e doente, e mantém na descrição de seus sintomas uma alternância entre o prazer e o horror: "Durante um tempo, esse enlevo apenas aumentou, até alcançar um determinado ponto; então, aos poucos, uma sensação medonha, cada vez mais intensa, misturou-se a tal prazer" (FANU, 2010, p.93). Durante o sono, tem sensações "vagas e estranhas": "se assemelhava ao calafrio prazeroso que sentimos quando, banhando-nos num rio, caminhamos contra a corrente"; ao mesmo tempo em que "sonhos intermináveis", dos quais não se lembra nitidamente, "causavam uma impressão terrível, e uma sensação de esgotamento físico, como seu eu tivesse sido exposta a situações de perigo" (FANU, 2010, p.94). Ainda assim, duvida estar sendo atacada pelo oupire, cujas vítimas ela ouvia dizer que faleciam em dias; e não desconfia de Carmilla, até que em sonho, ouve uma voz: 
"Tua mãe te adverte a tomares cuidado com o assassino", momento em que surge uma luz e revela-se a imagem de Carmilla, "de pé, ao lado da minha cama, com sua camisola branca, coberta do queixo aos pés por uma imensa mancha de sangue" (FANU, 2010, p.95).

Ainda assim, Laura não associa esta cena à sucção de seu próprio sangue por Carmilla, mas pensa que isto seria um aviso de que a amiga estaria sendo assassinada. Sua identidade vampiresca só é suspeitada pela narradora quando esta ouve o relato do General Spieldorf, que recebera uma hóspede misteriosa e com os mesmos hábitos de Carmilla, e cuja filha, a qual apresentava os mesmos sintomas que Laura, falecera. O relato se dá nas ruínas do vilarejo de Karnstein, onde o general fora à procura do túmulo da Mircalla, a condessa vampira. Apenas ao final do livro a figura de Carmilla/ Mircalla é explicitamente descrita como vampira, abundantemente banhada em sangue:

A sepultura da condessa Mircalla foi aberta; o general e meu pai reconheceram, na face agora exposta, a bela e pérfida hóspede. Embora 150 anos houvessem se passado desde o funeral, a fisionomia se mostrava corada com o calor da vida. Os olhos estavam abertos; o caixão não exalava qualquer fedentina cadavérica. Os dois médicos, um ali presente, o outro representado pela pessoa do promotor público, atestaram fatos absolutamente fabulosos: uma tênue respiração e um breve batimento cardíaco. Os membros superiores e inferiores se mostravam flexíveis, a pele elástica, o caixão forrado de chumbo estava inundado de sangue, com uma profundidade de cerca de vinte centímetros, e naquele sangue o corpo flutuava. (FANU, 2010, p.140) 
Nota-se claramente, nos capítulos finais de Carmilla, a influência dos relatos presentes no Traités sur les revenants..., de Calmet, no que se refere às características da vampira em seu caixão e em sua execução, bem como na citação de autoridades e relatos oficiais/ jurídicos sobre o caso.

Além da ambiguidade entre a beleza/sedução e a figura monstruosa, temos também em Carmilla, assim como em La morte amoureuse, um sentimento amoroso pela vítima, e, neste ponto, é possível supor, a partir da menção de Laura ao fato de as vítimas dos vampiros morrerem em dias, que Carmilla estaria retardando sua morte, bebendo seu sangue aos poucos para evitá-la, como ocorre com Clarimunda em relação a Romualdo. Entretanto, em Carmilla, a relação entre o amor e a morte é explícita: em vários momentos da narrativa, ela declara a Laura, em palavras que a narradora diz não compreender, a perspectiva de que Laura se tornaria uma vampira, e de uma união entre elas na morte:

No êxtase da minha tremenda humilhação, vivo no calor da tua vida, e tu hás de morrer... morrer languidamente... na minha. Não consigo evitá-lo; assim como me aproximo de ti, vais te aproximar de terceiros, e tomarás consciência do êxtase dessa crueldade, que contudo não deixa de ser amor (...).

Mas, morrer como amantes... morrer juntas, para poder viver juntas. Meninas são lagartas enquanto vivem neste mundo, mas se transformam em borboletas quando chega o verão; no entanto, nesse ínterim, há vermes e larvas, você entende?

Com um olhar tímido e estranho, apressou-se em esconder o rosto no meu pescoço, entre os meus cabelos, suspirando sofregamente, quase 
soluçando, e apertando a minha mão com suas mãos trêmulas.

Sua face macia brilhava ao lado da minha.

- Querida, querida - ela murmurou. - Vivo em ti; e morrerás por mim; amo-te demais. (FANU, 2010, p.67; 77; 82, respectivamente - G6++rifos da autora)

Se em Carmilla, assim como em A morta amorosa, as protagonistas vampiras oscilam entre a beleza e a animalidade, e estabelecem relações amorosas com suas vítimas, algo diverso ocorre com Drácula, protagonista do romance homônimo de Bram Stoker. Assim como Lord Ruthven e Carmilla, ele possui origem nobre e hábitos aristocráticos. A influência da novela de Fanu é evidente no romance de Stoker, cujo cenário inicial é também o leste europeu, mais precisamente a Transilvânia, "umas das regiões mais selvagens e menos conhecidas da Europa" (STOKER, 2015, p.28). Para lá dirige-se Jonathan Harker, um jovem advogado de uma firma imobiliária, para negociar com o Conde Drácula a aquisição de propriedades em Londres. Aos poucos, Jonathan não apenas descobre-se prisioneiro do conde em seu isolado castelo, mas também a identidade demoníaca de seu anfitrião, registrando em seu diário as descrições de Drácula e os fatos insólitos e terríveis que presencia.

Enquanto Jonathan luta para fugir do castelo de Drácula e, depois, recupera-se em um hospital, este dirige-se a Londres, cidade em que faz de sua primeira vítima a jovem Lucy, pupila da srta. Mina Murray, a qual, por sua vez, era noiva de Jonathan e, posteriormente, será também atacada pelo vampiro. Depois da morte de Lucy e 
da leitura do diário de Jonathan, Mina escreve ao famoso Dr. Van Helsing, antigo professor do Dr. Seward - médico e amigo de Lucy e de seu noivo, Arthur, e de Quincey, um jovem americano também apaixonado por esta e que se junta a eles na caçada e extermínio de Drácula. O romance é composto pela alternância dos diários de tais personagens, e esta polifonia narrativa é uma das grandes novidades de Stoker em relação às narrativas vampirescas precedentes. Entretanto, como o foco deste texto é demonstrar a ambiguidade da personagem vampiresca entre o cadavérico/monstruoso e o belo/humanizado já no século XIX, deixemos a síntese do enredo e a questão da polifonia narrativa para analisarmos as descrições de Drácula, das três vampiras que quase atacam Jonathan e de Lucy.

Já no primeiro encontro com Drácula, Jonathan se revela confuso com os hábitos corteses do conde, os quais parecem destoar de sua aparência cadavérica e animalesca: Drácula é descrito como um homem "alto e velho, inteiramente barbeado com exceção de um longo bigode branco e trajando preto das cabeças aos pés"; ele o convida para entrar em seu castelo "com um gesto cordial" e "em inglês perfeito", mas avança "impulsivamente" sobre seu hóspede, assim que este cruza a porta, agarrando sua mão "com uma força que me fez retrair, efeito que não foi atenuado pelo fato de que sua pele era fria como gelo, parecendo mais a de um homem morto" (STOKER, 2015, p.45). O conde gentilmente carrega suas malas e oferece-lhe uma boa ceia; porém, embora Jonathan afirme que "as boas vindas corteses do conde pareceram dissipar todas as minhas dúvidas e receios", não deixa de observar sua "fisionomia bastante marcada":

A boca, pelo que pude ver sob o bigode grosso, era rígida e parecia até cruel, com dentes particularmente 
pontiagudos e brancos. Estes se ressaltavam por sobre os lábios, cujo notável rubor demonstrava uma impressionante vitalidade para um homem naquela idade. De resto, as orelhas eram pálidas e extremamente pontudas no alto. O queixo era largo e forte, e as maçãs firmes, embora magras. O efeito geral era de uma extraordinária palidez.

Até ali, só havia reparado no dorso das mãos dele quando postadas sobre os joelhos e à luz do fogo, e me pareceram bastante brancas e magras. Mas vendo-as agora de perto, não pude evitar notar que eram mãos bastante ásperas, largas, de dedos curtos e gordos. Estranhamente, havia pelos no centro da palma. As unhas eram compridas, finas e cortadas em pontas afiadas. Quando o conde inclinou para mim e suas mãos me tocaram, não pude evitar um calafrio. Talvez porque seu hálito era fétido, mas uma terrível sensação de náusea se apoderou de mim, que, por mais que me esforçasse, não consegui disfarçar. O conde, evidentemente, reparando nisso, recuou. E, com uma espécie de sorriso taciturno, que exibiu mais do que até então seus dentes protuberantes, sentou-se novamente de seu lado da lareira. (STOKER, 2015, p.47)

A descrição do primeiro encontro com Drácula, bem como das características físicas do personagem, sugere sua condição de animalidade e explicita a reação de repugnância de Jonathan a elas, o que difere significativamente da descrição do primeiro encontro de Clarimunda e Carmilla com suas amadas vítimas, e da aparência inicial destas vampiras, na qual predomina a descrição da beleza, da sensualidade e da atração exercida sobre Romualdo e Laura, respectivamente.

Ao longo do romance, os aspectos animalescos, repugnantes e monstruosos de Drácula ficarão cada vez mais explícitos. Entretanto, 
há uma diferença de caracterização entre este vampiro e as vampiras retratadas no romance, que são representadas pelo aspecto da beleza ou da sedução. As primeiras vampiras que aparecem na narrativa são as "três jovens damas" que abordam Jonathan quando este, desrespeitando as ordens do conde de se manter apenas em uma ala do castelo, adormece em uma sala que, outrora, deveria ter sido recinto para repouso ou recreação femininas:

As três tinham dentes brancos brilhantes que reluziram feito pérolas contra o rubi de seus lábios voluptuosos. Havia neles algo que me inquietava, um certo desejo e ao mesmo tempo um certo medo mortal. Senti no coração o impulso cruel e ardente que me beijassem com aqueles lábios rubros. (...)

Fiquei deitado, calado, espreitando, numa agonia de deliciosa ansiedade. A loira veio e se inclinou sobre mim até que senti o movimento de sua respiração. Em certo sentido, era um hálito doce feito mel, e produzia o mesmo tilintar de nervos de sua voz, mas com um amargor subjacente à doçura, um amargor agressivo como o que se sente no cheiro de sangue.

(...) A moça ajoelhou-se e inclinou-se sobre mim, simplesmente entregue ao próprio prazer maligno. Havia uma voluptuosidade deliberada que era ao mesmo tempo excitante e repulsiva, e, quando arqueou o pescoço, chegou de fato a lamber os lábios feito um bicho, até que pude ver à luz da lua a umidade cintilante de sua boca escarlate e da língua vermelha deslizando sobre os dentes pontiagudos. A jovem baixou cada vez mais a cabeça, à medida que descia os lábios por minha boca e ao longo de meu queixo, e parecia prestes a fechá-los em minha garganta. (...) Concentrei-me no toque macio e trêmulo dos lábios na pele hipersensível e 
nas pontas duras de dois dentes pontiagudos, que apenas me tocaram e se detiveram. Fechei os olhos num êxtase langoroso e aguardei, com o coração acelerado. (STOKER, 2015, p.71)

A descrição contém o erotismo já presente em Carmilla, apresentando as sensações de Jonathan com a mesma ambiguidade entre repulsa e desejo presente na novela de Fanu, porém, com predominância do segundo, na descrição do contato físico com a vampira. Embora ela não seja descrita propriamente como bela, mas "como um bicho", ela é atraente, tem lábios rubros e voluptuosos, e, ao contrário do conde, seu hálito é doce, e seu toque é macio (enquanto o de Drácula gera calafrios). Mas, em relação à beleza, é Lucy quem contraria a imagem do monstro, ao ser vista por Dr. Seward em seu caixão, meses depois de sua morte:

Lá estava Lucy, aparentemente como a havíamos visto na noite anterior ao enterro. Estava, se isso é possível, ainda mais radiantemente bela do que nunca, e mal pude acreditar que estivesse mesmo morta. Os lábios estavam vermelhos, não, mais rubros do que antes, e, nas faces, um delicado rubor. (STOKER, 2015, p.257)

Porém, posteriormente, Lucy também é apresentada como um monstro, quando chega a seu mausoléu com uma das suas vítimas. Mas, flagrada por Arthur, Seward e Van Helsing, tenta seduzir o ex-noivo:

A doçura havia se convertido em crueldade adamantina, impiedosa, e a pureza, em voluptuosa promiscuidade. (...) Com a luz concentrada sobre o rosto de Lucy, pudemos ver que os lábios estavam vermelhos de sangue fresco e que o fio escorrendo pelo queixo manchara a pureza da mortalha branca. 
(...) Ao nos fitar, seus olhos reluziram com um brilho profano, e o rosto se enfeitou com um sorriso voluptuoso. Oh, meu Deus, como estremeci ao presenciar aquilo! Com um movimento descuidado, cruel feito um demônio, ela jogou no chão a criança que até então trazia agarrada com força ao peito, rosnando feito um cão diante de um osso. (...) 0 sangue-frio deste gesto fez Arthur gemer também. Quando Lucy avançou na direção dele com os braços abertos e um sorriso lascivo, ele recuou e cobriu o rosto com as mãos. Mas ela continuou se aproximando dele e, cheia de langor e volúpia, o chamou (...).(STOKER, p.269-270)

Havia algo de diabolicamente meigo naquele tom de voz, algo que lembrava o tilintar do vidro e que ressoou em nossos cérebros mesmo que as palavras tenham sido dirigidas a outro homem. Quanto a Arthur, parecia em transe e, tirando as mãos do rosto, abriu os braços. (STOKER, p.269-270)

Novamente, na descrição de Lucy, a imagem da vampira é associada à sedução, embora não se poupem detalhes também na descrição de sua crueldade. Porém, essa ambiguidade não se constata na figura de Drácula, o protagonista, que nunca é descrito como belo ou atraente. Ele domina Lucy e Mina, faz com que entrem em transe e alimenta-se do sangue delas, mas em nenhuma parte do romance, nos diários destas personagens, encontram-se em seus relatos sensações voluptuosas associadas ao conde. Ao contrário, a sensação de contato físico com ele é descrita como apavorante e repulsiva:

Ao lado da cama, como que saído de dentro da neblina, ou melhor, como se a neblina tivesse se condensado em sua figura, pois sumira inteiramente, havia um homem alto, magro e todo de preto. 
Reconheci-o imediatamente pelas descrições. (...) Por um momento, meu coração parou de bater, eu teria gritado se não estivesse paralisada. Nesse meio tempo, ele falou, num sussurro agudo e cortante, apontando para Jonathan:

"Silêncio! Se der um pio, esmago os miolos dele na sua frente". Fiquei apavorada e perplexa demais para fazer ou dizer qualquer coisa. Com um sorriso de escárnio, ele me segurou firme pelo ombro com uma das mãos e despiu meu pescoço com a outra, dizendo: "Primeiro, um pouco de refresco em recompensa por meu esforço. Melhor ficar quieta. Não é a primeira nem a segunda vez que suas veias aplacam minha sede!" Eu estava aturdida e, estranhamente, não quis impedi-lo. Suponho que seja parte da maldição horrível que recai sobre a vítima quando ele a toca. $E$, oh, meu Deus, meu Deus, tenha piedade de mim! Ele pôs os lábios fétidos em meu pescoço. (...)

Senti minha força se esvaindo, como se fosse desmaiar. Não sei dizer por quanto tempo essa coisa horrível durou, mas me pareceu uma eternidade até que ele retirasse sua boca asquerosa, impura e insolente de meu pescoço. Vi que estava pingando de sangue fresco. (STOKER, 2015, p.357-358)

Nesta cena, em que Mina relata a Van Helsing o ataque de Drácula, chama a atenção a postura ameaçadora do conde. Ao contrário de persuadir pela sedução, ele ameaça matar Jonathan, e domina a vontade de Mina para que ela se submeta a ele, deixando-o sugar seu sangue. Nenhum cuidado ou remorso é demonstrado neste ato, motivado apenas pelo "aplacar a sede" - Drácula serve-se do sangue de Mina como o de qualquer outro ser humano, não demonstrando nenhum afeto pela vítima. Ao 
contrário das bocas voluptuosas das vampiras, a expressão "lábios fétidos" e os adjetivos "asquerosa, impura e insolente" explicitam a repulsa causada ao contato físico do vampiro.

Depois de ter sido atacada por Drácula, Mina sente-se impura, afirmando que não poderia mais tocar nem beijar Jonathan (STOKER, 2015, p.354). Mina não se transforma em uma vampira porque, antes que ela morresse, Drácula é morto, depois de perseguido de Londres até seu castelo na Transilvânia. Mas ela faz Van Helsing prometer-lhe que, se necessário, ele a mataria e queimaria seu corpo, libertando sua alma do destino terrível de ser tornar um ser asqueroso e demoníaco. A reação de Mina difere significativamente das reações de Romualdo e Laura - aquele sente saudades de Clarimunda, sua grande paixão; esta se sente apenas aliviada por ter sobrevivido ao perigo por qual passou, mas não declara se sentir impura ao descobrir que travou relações tão íntimas com uma vampira. Nenhum dos dois expressa qualquer temor de tornaremse também vampiros depois de suas mortes.

\section{CONSIDERAÇÕES FINAIS}

Chegamos ao fim deste percurso de leituras de narrativas vampirescas, no qual explicito as variações da imagem do vampiro ao longo do tempo e de diversas obras, com o intuito de analisar como algumas caracterizações deste personagem em obras contemporâneas se formaram ao longo dos séculos XVIII e XIX.

A princípio, parecia-me que a narrativa vampiresca literária ia se distanciando da imagem do vampiro dos relatos míticos, de forma que, a partir do século XIX, teríamos um vampiro limpo, integrado socialmente, associado à sedução. Mas uma leitura atenta das obras 
descritas neste trabalho revelou-me de fato uma alternância de imagens, por vezes, sutilmente, dentro de uma mesma obra: a do vampiro monstruoso (cadavérico, repugnante, fétido, animalesco, obcecado por sangue), que causa medo e terror nas vítimas; e a do vampiro humanizado, aristocrático ou pertencente a uma classe econômica dominante (fisicamente atraente, sedutor, persuasivo), que não apenas conquista suas vítimas para sugar-lhes o sangue, mas estabelece relacionamentos com e apresenta sentimentos por elas.

Portanto, não há como estabelecer uma distinção entre estas duas imagens tomando por critério a cronologia das obras, pensando-se que as mais antigas se aproximariam mais do vampiro mítico monstruoso, enquanto, nas mais recentes, prevaleceria a imagem do vampiro literário humanizado - hipótese que se desfez na comparação entre A morta amorosa, de Gautier, Carmilla, de Fanu, e Drácula, de Stoker. Conforme explicitado ao longo deste artigo, na primeira, de 1836, a personagem vampira é quase sempre bela, sedutora e amorosa; na segunda, de 1874, apenas ao final se tem a figura de Carmilla como um monstro, mas ao longo da narrativa, ela também é uma jovem nobre e atraente; e no terceiro, que está no limiar do século XX (1897), Lucy e outras vampiras são atraentes e sedutoras, enquanto Drácula é um vampiro que se aproxima muito da imagem animalesca e monstruosa, no máximo, configurando-se como misterioso, mas nunca sedutor.

A análise destas obras e a constatação da ambiguidade entre os aspectos monstruosos e humanos na personagem vampiresca nos leva a constatar, enfim, que a representação do vampiro belo, atraente, e que sente culpa ou pesar por se alimentar do sangue de vítimas, por quem eventualmente se apaixona, não é tão inovadora 
quanto parece e bem anterior às narrativas de Meyer, ou mesmo às de Anne Rice. Clarimunda e Carmilla são as ancestrais oitocentistas de Louis, Edward e outros vampiros belos e apaixonados de narrativas contemporâneas.

\section{REFERÊNCIAS}

BAUDELAIRE, Charles (1857). Les fleurs du mal. Paris: Poulet-Malassis et De Broise Libreurs-Éditeurs. Bibliotèque Nacionale de France. In https://gallica.bnf. fr/ark:/12148/bpt6k1057740n/f9.item Acesso em 15.Fev.2019.

CALMET, Augustin (1751). Traités sur les apparitions des esprits, et surles vampires, ou les revenans de Hongrie, de Moravie, \& c. Nouvelle édition revûe, corrigeé \& augmentée par l'Auter. Tome II. Paris: Chez Débure l'aîné. Fonte: Bibliotèque Nacionale de France. In http://gallica.bnf.fr/ark:/12148/bpt6k68180w/f2.image Acesso em 15.Fev.2019.

CLARK, Lynn Schofield (2005). "Touched by a vampire named Angel", In: From Angels to Aliens: Teenagers, the Media and the Supernatural. New York: Oxford University Press, p.46-73.

COSTA, Bruno (Org.) (2010). Contos clássicos de vampiro. São Paulo: Hedra.

FANU, Sheridan Le (2010). Carmilla - A vampira de Karnstein. São Paulo: Hedra. FERRAZ, Salma; MARTINS, Leonor (2017). "Vampiros: o mito é o nada que é tudo e de todos". In: FERRAZ, Salma; LOYOLLA, Dirlenvalder; MARTINS, Patrícia Leonor; CANÊDO, Cátia (Orgs.). Sobre o vampirismo de Drácula a Crepúsculo: a saga do vampiro na cultura ocidental. São Paulo: Todas as Musas. p.9-30.

FREUD, Sigmund (2012). Totem e tabu. Algumas concordâncias entre a vida psíquica dos homens primitivos e a dos neuróticos. São Paulo: Penguin \& Companhia das Letras.

KOHN, Max (2012). "O vampiro, um não morto ainda vivo". Revista Ágora, Rio de Janeiro. XV(2), jul/dez, 301-309.

KOKKOLA, Lydia (2011). "Virtuous vampires and Voluptous Vamps: Romance Conventions Reconsidered in Stephenie Meyer's 'Twilight' Series". Children's Literature in Education, jun, 42, 165-179, In https://link.springer.com/ article/10.1007/s10583-010-9125-9 Acesso em 20.Jun.2019. 
LECOUTEUX, Claude (2005). História dos vampiros: autópsia de um mito. São Paulo: Editora UNESP.

MEYER, Stephenie (2008). Twilight. London: Atom. (2009). New Moon. London: Atom.

ROAS, David (2012). "Mutaciones pós-modernas: del vampiro depredador a la naturalización del monstruo" Revista Letras \& Letras. Uberlândia-MG, 28(2), jul./dez.

(2014) "El monstruo pós-moderno y los limites de lo fantástico", In: GARCIA, Flávio; BATALHA, Maria Cristina; MICHELLI, Regina (Orgs.). (Re)Visões do Fantástico: do centro às margens, caminhos cruzados. Rio de Janeiro: Dialogarts Publicações.

STOKER, Bram (2015). Drácula: edição comentada. Rio de Janeiro: Zahar.

ULIANO, Cristiane Gonçalves. "O vampiro do século XXI: a recriação do mito", In: FERRAZ, Salma; LOYOLLA, Dirlenvalder; MARTINS, Patrícia Leonor; CANÊDO, Cátia (Orgs.). Sobre o vampirismo de Drácula a Crepúsculo: a saga do vampiro na cultura ocidental. São Paulo: Todas as Musas. p.185- 200. 